\title{
Diffusion of Glucose, Insulin, Inulin, and Evans Blue Protein into Thoracic Duct Lymph of Man*
}

\author{
Eugenio A. Rasio, † Constantine L. Hampers, J. Stuart Soeldner, and \\ GEORGE F. CAHILL, JR. $\neq$ \\ (From the Elliott P. Joslin Research Laboratory and the Renal Transplant Unit, Department \\ of Medicine, Peter Bent Brigham Hospital and Harvard Medical School, and the \\ Diabetes Foundation, Inc., Boston, Mass.)
}

\begin{abstract}
Summary. Immunoreactive insulin, like inulin, quickly equilibrates with interstitial fluid, as evidenced by recovery in thoracic duct lymph in man. Insulin-like activity not accounted for by immunoreactive insulin behaves as a large protein and is confined to the vascular compartment.
\end{abstract}

\section{Introduction}

Although insulin has been extracted, purified in crystalline form, and recently synthesized, insulin as it exists in body fluids, particularly in man, has not been isolated or chemically characterized. Therefore, we can only refer to circulating insulin as "the activity in plasma that mimics the action of crystalline pancreatic insulin in one or more specific systems" (1).

Pancreatic insulin can be bound to a specific antibody; the plasma activity that exhibits a similar specific binding is called immunoreactive insulin (IRI). Extracted pancreatic insulin also enhances glucose metabolism in a variety of in vivo and in vitro biological systems, but because they lack specificity the plasma activities detected with these biological techniques are called insulin-like activity (ILA). In some bioassays, one or more circulating ILA that are not immunochemically reactive can be measured; these components of plasma ILA, not accounted for by IRI, have been

* Submitted for publication December 1, 1966; accepted February 10, 1967.

Supported in part by U. S. Public Health Service grants T1 AM-5077-11, AM-09584-02, AM-09748-02, and 8 M01-FR-31-05, and the John A. Hartford Foundation, Inc., New York, and the Adler Foundation, Inc., Rye, N. Y.

† International postdoctoral fellow of the National Institutes of Health.

$\ddagger$ Investigator, Howard Hughes Medical Institute. Address requests for reprints to Dr. George F. Cahill, Jr., Diabetes Foundation, Inc., 170 Pilgrim Rd., Boston, Mass. 02215 . called "bound," "atypical," or "nonsuppressible" insulin. A critical review of the state of insulin in blood has recently been made by Berson and Yalow (1).

Few in vitro investigations have attempted to elucidate the nature of plasma insulin; there is some indirect evidence that most of the circulating IRI exists as a relatively small molecule (1-3), whereas the fraction of plasma ILA immunologically inactive may be composed of one or more species of larger molecules, obtained either by polymerization of a smaller unit (4) or by binding to a carrier protein (5).

In this study, an attempt has been made to characterize in vivo some physiochemical properties of circulating insulin. Diffusion of molecules through blood capillaries is dependent upon molecular weight, protein interactions, and other factors. Therefore, the ability of intravascular insulin to equilibrate with thoracic duct lymph in man was compared to the diffusion of glucose (mol wt 180), inulin (mol wt approximately 5,500), and Evans blue-stained plasma protein (mol wt approximately 69,000). Intravascular insulin was either endogenous hormone released after a rapid glucose load or exogenous crystalline pork hormone injected intravenously.

\section{Methods}

Six patients with chronic renal failure and bilateral nephrectomy were investigated. They were maintained in good nutritional and metabolic balance by intermittent hemodialysis and transfusions (Table I). There 
TABLE I

Metabolic data in the six patients during testing periods

\begin{tabular}{|c|c|c|c|c|c|c|c|c|c|}
\hline Patient & Sex & Age & Weight & BUN* & $\mathbf{K}$ & $\mathrm{CO}_{2}$ & $\begin{array}{c}\text { Hemato- } \\
\text { crit }\end{array}$ & $\begin{array}{c}\text { Serum } \\
\text { protein } \\
\text { albumin/ } \\
\text { total }\end{array}$ & $\begin{array}{l}\text { Lymph } \\
\text { protein } \\
\text { albumin/ } \\
\text { total }\end{array}$ \\
\hline & & years & $k g$ & $\begin{array}{c}\mathrm{mg} / \\
100 \mathrm{ml}\end{array}$ & $m E q / L$ & mmoles $/ L$ & $\%$ & \multicolumn{2}{|c|}{$\mathrm{g} / 100 \mathrm{ml}$} \\
\hline $\begin{array}{l}1 \\
2 \\
3 \\
4 \\
5 \\
6\end{array}$ & $\begin{array}{l}\mathrm{M} \\
\mathrm{M} \\
\mathrm{F} \\
\mathrm{M} \\
\mathrm{M} \\
\mathrm{M}\end{array}$ & $\begin{array}{l}32 \\
26 \\
39 \\
25 \\
24 \\
30\end{array}$ & $\begin{array}{l}60 \\
81 \\
54 \\
65 \\
60 \\
52\end{array}$ & $\begin{array}{l}86 \\
42 \\
50 \\
42 \\
52 \\
31\end{array}$ & $\begin{array}{l}5.7 \\
4.1 \\
5.1 \\
3.8 \\
4.6 \\
4.7\end{array}$ & $\begin{array}{l}24 \\
24 \\
24 \\
29 \\
28 \\
26\end{array}$ & $\begin{array}{l}33 \\
22.5 \\
25 \\
29 \\
32 \\
25\end{array}$ & $\begin{array}{l}3.0 / 6.2 \\
3.2 / 5.1 \\
2.7 / 5.5 \\
3.7 / 5.7 \\
3.0 / 5.2 \\
3.9 / 6.5\end{array}$ & $\begin{array}{l}2.0 / 3.7 \\
1.8 / 2.4 \\
1.7 / 3.1 \\
1.6 / 2.0 \\
2.6 / 4.2\end{array}$ \\
\hline
\end{tabular}

* Blood urea nitrogen.

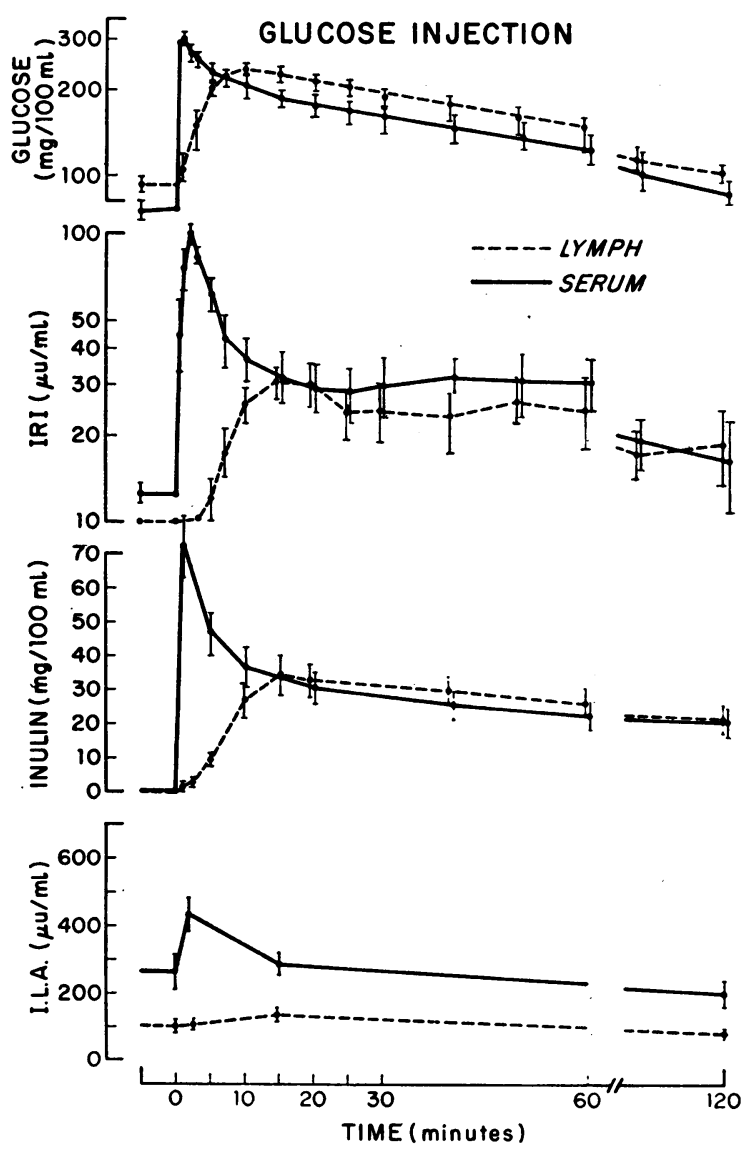

Fig. 1. Concentration of glucose, immunoreactive INSULIN (IRI); INULIN, AND INSULIN-LIKE ACTIVITY (ILA) IN LYMPH AND SERUM AFTER RAPID INTRAVENOUS ADMINISTRATION OF GLUCOSE AND INULIN TO SIX ANEPHRIC SUBJECTS. No correction was made for the delay in lymph collection via the thoracic duct cannula, which explains the dissociation from an ideal precursor-product relationship. was no clinical evidence of edema or congestive heart failure; blood urea nitrogen never achieved the concentrations known to increase capillary permeability (6). Each patient as part of his treatment before renal transplant had a thoracic duct cannulation and a forearm arteriovenous bypass and was scheduled for glucose and insulin tolerance tests. During testing periods these patients were afebrile, consuming daily a diet of at least $200 \mathrm{~g}$ carbohydrate and 2,000 calories, and not receiving steroids, immunosuppressive drugs, or thiazides. Two tests were performed; the first was an intravascular injection of a mixture of $50 \%$ glucose in water and $10 \%$ inulin $^{1}$ in water, for a total amount of $0.5 \mathrm{~g}$ per $\mathrm{kg}$ body weight of glucose and $5 \mathrm{~g}$ of inulin. The second was an intravascular injection of a mixture of $80 \mathrm{U}$ per $\mathrm{ml}$ of crystalline pork insulin ${ }^{2}$ and $10 \%$ inulin in water. Dosage was $0.1 \mathrm{U}$ per $\mathrm{kg}$ body weight of insulin and $2.5 \mathrm{~g}$ of inulin. In four patients, $25 \mathrm{mg}$ of a $5 \%$ aqueous solution of Evans blue ${ }^{1}$ was added to the solution to be injected.

These tests were performed on each patient on consecutive days after an overnight fast. The solutions were injected intravenously via the shunt in approximately 30 seconds.

Simultaneous samples of thoracic duct lymph and arterial blood were timed after the end of the injection. When lymph flow did not allow a collection of adequate amounts of lymph, samples were obtained within \pm 30 seconds of the alleged time. Furthermore, in timing the lymph samples, the changes in flow and the dead space of the thoracic duct catheter were not taken into account. The relative diffusion rates of glucose, insulin, inulin, and Evans blue protein were compared within the same patient. The samples of blood and lymph were allowed to clot at room temperature for 4 hours; after centrifugation, the supernatant serum and cell-free lymph were collected and stored at $-20^{\circ} \mathrm{C}$. Glucose was measured by the glucose oxidase method; its disappearance rates after the glucose load $(\mathrm{K})$ or after insulin injection ( $\mathrm{i}=$ net glucose disappearance rate between 5 and 30

1 Warner-Chilcott, Morris Plains, N. J.

2 Eli Lilly Co., Indianapolis, Ind., courtesy of Dr. W. R. Kirtley. 
minutes) were estimated by the slope of time against the logarithm of concentration and expressed as the per cent disappearing per minute $(7,8)$.

Inulin was determined with resorcinol after the samples were preincubated with purified glucose oxidase (9). Evans blue was measured by colorimetry after extraction from the carrier protein (10). Immunoreactive insulin was assayed in duplicate, at a $1: 10$ dilution, by a double-antibody technique (11). The results were expressed in microunits per milliliter of equivalent human crystalline insulin; in this immunoassay the affinities of the antibody for crystalline pork and crystalline human insulin were found to be identical. The half-time of IRI in serum and lymph after injection of exogenous insulin was computed on the basis of changes in the increment of IRI over fasting levels after equilibration of IRI in serum and lymph was achieved. The volumes of distribution of glucose, inulin, IRI, and Evans blue protein were determined by $V=Q /\left(C_{0}-C f\right)$, where $Q$ is the amount of the substance injected, $\mathrm{Cf}$ the initial fasting concentration in serum or lymph, and $C_{0}$ the theoretical value obtained by extrapolating to time 0 the slope of disappearance after equilibration. Insulin-like activity was measured by the conversion of glucose-1-14 $\mathrm{C}$ to ${ }^{14} \mathrm{CO}_{2}$ by the rat epididymal fat pad (12). Each sample of serum or lymph was assayed in triplicate at the dilution of $1: 4$, and the results were expressed in microunits per milliliter of equivalent crystalline pork insulin in whole serum or lymph. In this bioassay crystalline human and pork insulins exhibited the same activity.

\section{Results}

For ease of presentation, Figures 1, 2, and 3 contain the data expressed as a mean of all individual studies. However, the patterns and temporal relationships among the parameters in the pooled data are representative of each individual study.

Intravascular injection of glucose and inulin. This test allows a comparison of the diffusion of glucose, inulin, and endogenous insulin. The results are illustrated in Figure 1 and Table II.

Glucose was consistently the first substance to appear and peak in the thoracic duct lymph; a significant rise in lymph glucose was observed within 1 to 5 minutes after the intravascular injection, with a peak occurring between 7 and 15 minutes. After equilibration in vascular and extravascular compartments, glucose disappearance rates were similar in serum (mean $\mathrm{K}=1.2 \pm 0.2$ ) and lymph (mean $\mathrm{K}=1.2 \pm 0.1$ ). Glucose space calculated from glucose distribution in serum and lymph averaged, respectively, $33.6 \pm 2.8$ and $29.5 \pm 1.9 \%$ of body weight. Inulin and endogenous immunoreactive insulin had a similar pattern of diffusion

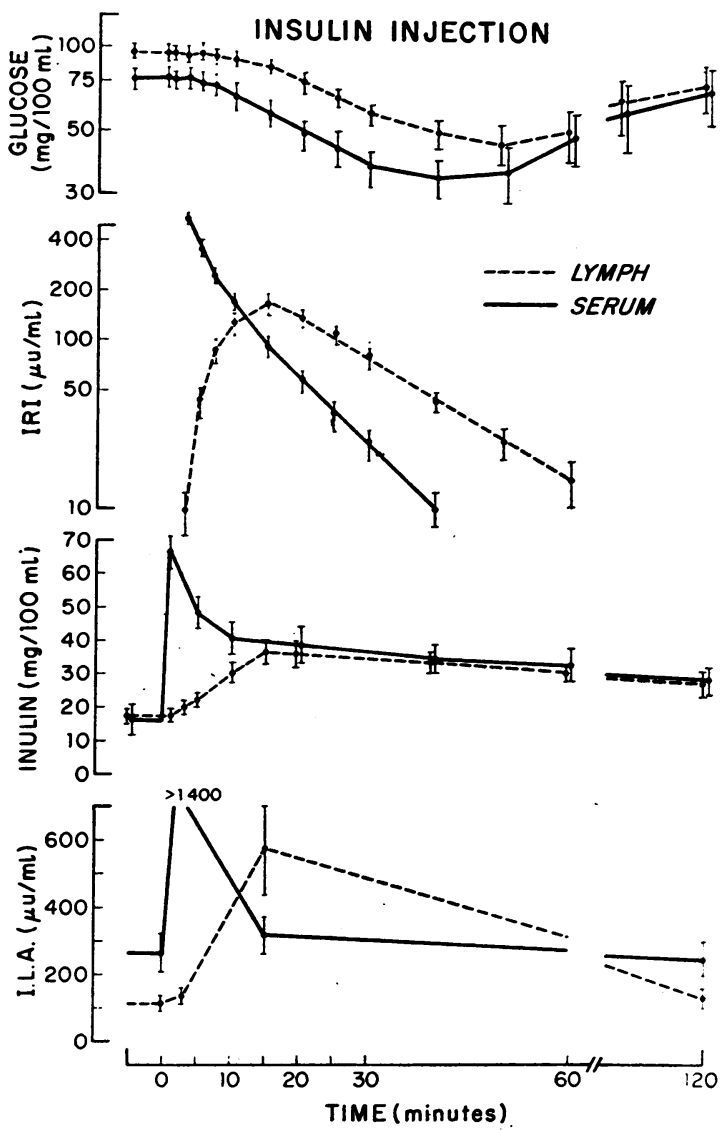

Fig. 2. Concentration of GLUCOSE, IRI, INULin, AND ILA IN LYMPH AND SERUM AFTER RAPID ADMINISTRATION OF INSULIN ( 0.1 U PER KG BODY WEIGHT) AND INULIN TO THE SAME SIX ANEPHRIC SUBJECTS. As in Figure 1, no correction was made for the delay in lymph collection via the thoracic duct cannula, but these data can be directly compared to those in Figure 1, assuming no change in the rate of lymph flow and no change in the dead space volume.

during the time required for their equilibration in serum and lymph. In each patient, their appearance and peak in lymph were similarly delayed when compared with glucose; both IRI and inulin increased in lymph within 3 to 7 minutes and peaked simultaneously within 15 to 20 minutes. Inulin was thereafter cleared slowly but significantly from serum and lymph, despite the absence of kidneys. The low disappearance rate of inulin in serum and lymph allowed the estimate of inulin volume, which represented, respectively, $24.5 \pm$ 2.1 and $23.7 \pm 1.2 \%$ of the body weight.

After the diffusion in lymph of the initial peak of serum insulin, the concentrations of immuno- 
TABLE II

Volumes of distribution of glucose, inulin, insulin, of injected glucose $(K)$, endogenous glucose $(i)$,

\begin{tabular}{|c|c|c|c|c|c|c|c|c|c|c|}
\hline \multirow[b]{2}{*}{ Patient } & \multicolumn{4}{|c|}{ Inulin space } & \multicolumn{4}{|c|}{ Insulin space } & \multicolumn{2}{|c|}{ Insulin disappearance rate } \\
\hline & Serum & $\% \mathrm{BW} \dagger$ & Lymph & $\% \mathrm{BW}$ & Serum & $\% \mathrm{BW}$ & Lymph & $\% \mathrm{BW}$ & Serum $t_{\frac{1}{3}}$ & Lymph t \\
\hline & $L$ & & $L$ & & $L$ & & $L$ & & \multicolumn{2}{|c|}{ minutes } \\
\hline 1 & $\begin{array}{l}16.1 \\
16.7\end{array}$ & $\begin{array}{l}26.8 \\
27.8\end{array}$ & $\begin{array}{l}15.2 \\
15.6\end{array}$ & $\begin{array}{l}25.3 \\
26.0\end{array}$ & 15.0 & 25.0 & 15.0 & 25.0 & 7.5 & 14.5 \\
\hline 2 & $\begin{array}{l}22.7 \\
21.3\end{array}$ & $\begin{array}{l}26.2 \\
24.6\end{array}$ & $\begin{array}{l}22.7 \\
20.0\end{array}$ & $\begin{array}{l}26.2 \\
23.1\end{array}$ & 22.7 & 26.2 & 26.1 & 30.2 & 10.0 & 13.0 \\
\hline 3 & $\begin{array}{l}9.1 \\
8.1\end{array}$ & $\begin{array}{l}16.6 \\
14.7\end{array}$ & $\begin{array}{r}11.1 \\
7.4\end{array}$ & $\begin{array}{l}20.0 \\
13.5\end{array}$ & 12.0 & 21.8 & 12.0 & 21.8 & 7.0 & 10.5 \\
\hline 4 & $\begin{array}{l}20.8 \\
20.8\end{array}$ & $\begin{array}{l}32.0 \\
32.0\end{array}$ & $\begin{array}{l}17.2 \\
20.8\end{array}$ & $\begin{array}{l}26.5 \\
32.0\end{array}$ & 18.6 & 28.6 & 21.3 & 32.8 & 7.0 & 13.5 \\
\hline 5 & $\begin{array}{l}14.7 \\
16.6\end{array}$ & $\begin{array}{l}24.5 \\
27.6\end{array}$ & $\begin{array}{l}13.5 \\
16.7\end{array}$ & $\begin{array}{l}22.5 \\
24.5\end{array}$ & 15.8 & 26.3 & 15.8 & 26.3 & 5.5 & 9.5 \\
\hline 6 & $\begin{array}{r}10.8 \\
8.3\end{array}$ & $\begin{array}{l}21.2 \\
16.7\end{array}$ & $\begin{array}{r}10.0 \\
8.3\end{array}$ & $\begin{array}{l}19.7 \\
16.7\end{array}$ & 13.0 & 25.5 & 13.8 & 27.0 & 6.0 & 12.5 \\
\hline & & $\begin{array}{l}24.5 \pm 2.1 \\
23.9 \pm 2.7\end{array}$ & & $\begin{array}{l}23.3 \pm 1.3 \\
22.6 \pm 2.7\end{array}$ & & $25.7 \pm 0.9$ & & $27.2 \pm 1.6$ & $7.2 \pm 0.6$ & $12.2 \pm 0.8$ \\
\hline
\end{tabular}

* In each patient, the upper figures were obtained after injection of glucose (first test) and the lower figures after injection of insulin (second test).

$\dagger$ Per cent of body weight.

$\ddagger$ Mean \pm standard error of the mean.

reactive insulin in both compartments were maintained at a relatively constant level above the fasting value throughout the duration of the test.

Insulin-like activity increased in serum at the second minute, when concentrations of immunoreactive insulin were maximal, then decreased and at 120 minutes was below the fasting level; no significant change in lymph ILA was observed.

Intravascular injection of inulin, insulin, and Evans blue. The data obtained with this second test are shown in Figures 2 and 3 and Table II.

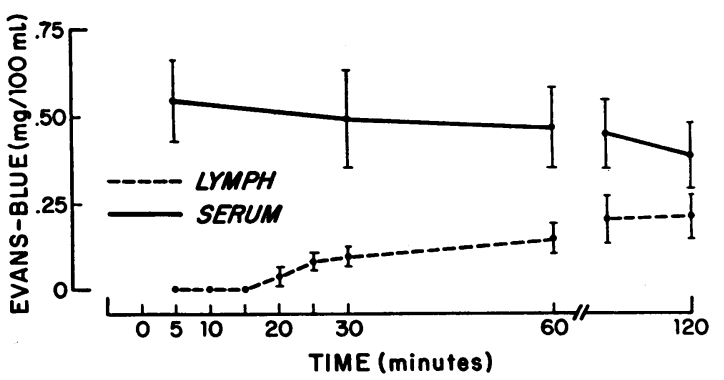

Fig. 3. Pooled data from four subjects Who ReCEIVED EVANS BLUE DYE INTRAVENOUSLY IN ADDITION TO INSULIN AND INULIN, SHOWING CONCENTRATIONS OF DYE IN LYMPH AND SERUM AS A FUNCTION OF TIME.
After the injection of insulin, glucose disappearance rates in serum and lymph were closely related during the first 30 minutes; $i=2.9 \pm 0.2$ in serum and $\mathrm{i}=3.1 \pm 0.4$ in lymph. Inulin peaked in lymph simultaneously with immunoreactive insulin; the characteristics of diffusion were similar to those obtained during the iv glucose tolerance test. Inulin spaces were $23.9 \pm 2.7$ and $22.6 \pm 2.7 \%$ of body weight. Insulin spaces were $25.6 \pm 0.9$ and $27.2 \pm 1.6 \%$ of body weight when calculations were performed as described in Methods.

The half-time of serum IRI after equilibration with lymph was $7.2 \pm 0.6$ minutes and of lymph IRI after the peak, $12.2 \pm 0.8$, a significant difference. The appearance and equilibration of Evans blue protein complex in lymph were considerably delayed compared with inulin and IRI (Figure 3 ). The volume of distribution of Evans blue protein averaged $6.2 \pm 0.7 \%$ of body weight.

ILA in serum and lymph followed a pattern similar to IRI. As observed during the first test, basal levels of ILA in lymph were considerably lower than in serum. 
TABLE II

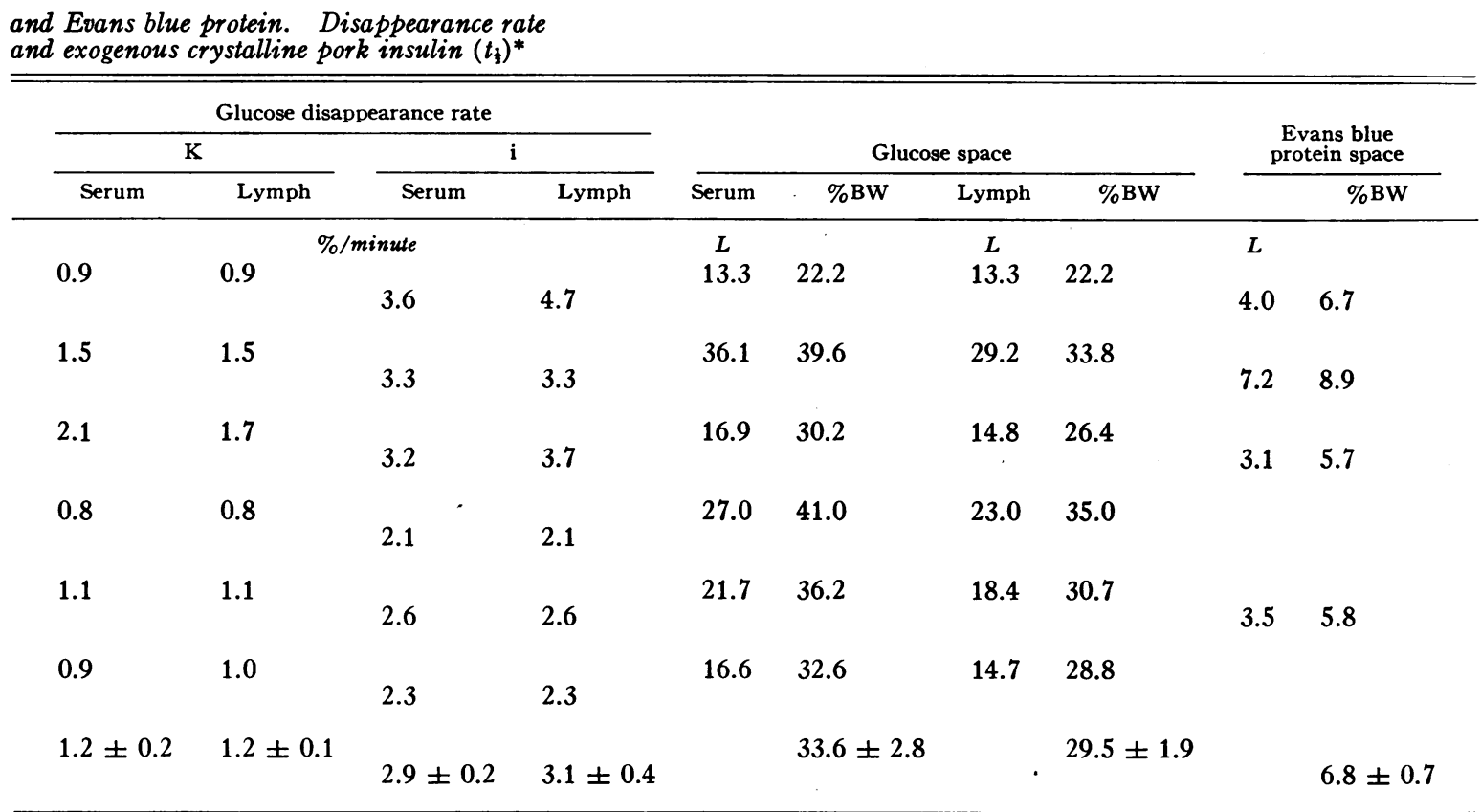

\section{Discussion}

The exchange of compounds between the blood and the extravascular fluid occurs mostly by diffusion; the rate of diffusion is determined by the size of the compound, a possible binding to other substances, and by the permeability of the capillary wall (13). Some characteristics of insulin transport in body fluids can therefore be investigated in vivo by comparing the ability of circulating insulin and tracer molecules to equilibrate with thoracic duct lymph. As capillary permeability is not uniform, varying amounts of lymph of different compositions are drained into the main lymphatic channels. In conditions of bed rest, thoracic duct lymph is mostly a mixture of liver and gastrointestinal lymph in unknown proportions. These viscera have a high turnover rate of proteins and highly permeable capillaries. Therefore, this study does not provide information for insulin equilibration through all body fluids, particularly those in muscle, fat, and brain. With these limitations in mind, the results indicate that the permeability of capillaries to glucose was the greatest of the compounds investigated. Disap- pearance rates of injected glucose and of endogenous glucose after insulin injection were similar in serum and lymph, suggesting a rapid diffusion of glucose back and forth across the capillary membrane; thus, the glucose assimilation by the cells depleted the vascular and extravascular pools simultaneously, as if they were a single pool.

In these nephrectomized patients, as in healthy normal subjects (11), a rapid infusion of glucose induced an immediate release of endogenous insulin, which peaked in blood, similar to that after a rapid intravascular injection of the hormone. This almost instantaneous release of insulin has also been reported with isolated perfused pancreas preparations (14). When inulin diffusion was compared with the diffusion of peak endogenous insulin, similar patterns were observed within the same individual, the equilibration time averaging 10 to 15 minutes. Thereafter, inulin and IRI were cleared slowly from both compartments, the slow inulin clearance due to the absence of kidneys and the apparent slow fall in insulin due to a continuous pancreatic secretion during the test.

For these data on endogenous insulin transport 
to be valid, no direct insulin secretion into the lymphatics of the pancreas should occur after a glucose load. If it did, some of the insulin in the thoracic duct lymph would have bypassed the blood capillary membrane. Although the possibility of a "lymphocrinie" has been suggested in the thyroid gland (15), the endometrial crypts (16), and the kidney (17), it seems unlikely for the endocrine pancreas; no lymphatics have been found in the islets of Langerhans (18), and no immediate and important rise in insulin concentration was observed in lymph collected from the cysterna chyli of rats after an intravenous load of glucose (19).

Further information can be obtained from the second test, when crystalline pork insulin, inulin, and Evans blue were simultaneously injected. Inulin and exogenous insulin again equilibrated simultaneously with thoracic duct lymph. Therefore, pancreatic extracted insulin and endogenous insulin released by glucose stimulation behave similarly to each other and to inulin in their ability to cross vascular membranes. The sensitivity of this in vivo procedure does not warrant the conclusion that endogenous and exogenous insulin are identical and that their molecular weight approximates 5,500 , as it is possible that small but significant differences in molecular weight could not be discriminated, although there were clear-cut differences among diffusion of glucose, inulin, and Evans blue protein. Furthermore, a similar diffusion of inulin and insulin does not necessarily imply that circulating insulin is a relatively small molecule; it is known, for instance, that free fatty acids in blood are strongly bound to albumin but very rapidly separated from their carrier protein as they move into extravascular fluids, the unbinding occurring at a capillary level (20). An analogous situation could be possible for insulin. Despite their limitations, the techniques employed in this study provide the only information available on the nature of insulin transport in vivo. That circulating immunoreactive insulin crosses the capillary membrane as a molecule smaller than Evans blue protein is in agreement with observations by Berson and Yalow, obtained with in vitro techniques; after ultracentrifugation of plasma, 60 to $80 \%$ of the IRI present in the uncentrifuged samples was found in the supernatant solution above the sedimentary boundary of the albumin (3). On starch gel electrophoresis, plasma insulin migrated in the immediate prealbumin zone (1). We concluded from these experiments that most of the plasma insulin is present as a small molecule unbound to serum protein.

Circulating immunoreactive insulin is cleared rapidly from the blood; the half-life of endogenous or exogenous insulin has been found to vary from 5 to 78 minutes $(1,21-24)$. In this investigation, the half-life of the injected insulin was measured after 10 to 15 minutes required for equilibration, the fasting value was subtracted, and pancreatic output of insulin was assumed to remain constant during the test. Our values of insulin half-life were consistently faster in serum than in corresponding lymph. This is in keeping with the hypothesis that insulin, after crossing capillary membranes, does not re-enter the vascular compartment at the same level but is carried away into the lymphatics; a similar phenomenon has been shown for other molecules of molecular weight greater than $6,000(13,25)$.

From the slope of disappearance of insulin in serum and lymph, a mean volume of insulin distribution was calculated; it approximates $26 \%$ of body weight for an inulin space of $23 \%$. These data are similar to a recent report in which injected insulin was shown to be distributed within the extracellular fluid (22).

A different volume of distribution would apply to the insulin-like activity not accounted for by IRI; this activity was indeed consistently lower in thoracic duct lymph than in serum after either an overnight fast or a glucose load. Similar results were obtained with rats (19). No insulin inhibitor, which might have lowered the glucose metabolism of the rat adipose tissue during the bioassay, was present in lymph, as shown by the good recovery of the activity of immunoreactive insulin as measured by lymph ILA after insulin injection (Figure 2) or insulin addition in vitro (19).

In our patients, after an overnight fast, lymph ILA represented only one-third of serum ILA, whereas the concentrations of IRI were similar in both compartments. This suggests that ILA not accounted for by IRI is a large molecule, mostly restricted to the vascular compartment, which may affect the metabolism of organs and tissues according to local capillary permeability. In interstitial fluids of tissues with low capillary perme- 
ability, low levels of ILA might be expected. In spinal fluid, for instance, where protein concentration is minimal, ILA is undetectable (26). In striated muscle and in adipose tissue, the capillary endothelium as examined by the electron microscope has no recognizable interstices, either intracellular, as in the intestinal villus, or intercellular, as in liver, spleen, and bone marrow sinusoids (27). Most likely, these tissues are little affected by serum ILA under in vivo physiological conditions. During bioassay using striated muscle or adipose tissue in vitro for ILA determinations, a nonphysiological situation is created as high concentrations of serum proteins, never achieved in vivo, are present in the incubation medium and directly in contact with the cellular surface.

After the intravascular injection of glucose, lymph ILA remained unchanged. If the early rise in serum ILA were a hormonal secretion distinct from the pancreatic secretion of IRI, our data again would indicate a high molecular weight for this hormone, as it would diffuse in thoracic duct lymph slower than Evans blue protein.

A few in vitro observations have been reported about the nature of nonimmunoreactive insulin. During dialysis in Visking tubing, atypical insulin behaved like a molecule of molecular weight greater than 40,000 (28); gel filtration of serum on Sephadex G-200 at $\mathrm{pH} 7.2$ revealed a molecular weight of nonsuppressible insulin-like activity between 100,000 and 200,000 (4). Chromatography on Sephadex G-75 and G-100 indicated a molecular weight for bound insulin between 60,000 and 100,000 (29). Thus, our in vivo investigation has provided information on ILA transport that is in agreement with in vitro estimates of ILA molecular weight.

\section{Acknowledgments}

We gratefully acknowledge the cooperation of Drs. J. E. Murray and J. P. Merrill in allowing us to study their patients. The technical assistance of Mrs. Dzidra Rumba is greatly appreciated.

\section{References}

1. Berson, S. A., and R. S. Yalow. Insulin in blood and insulin antibodies. Amer. J. Med. 1966, 40, 676.

2. Hall, J. L. Moving boundary electrophoretic study of insulin. J. biol. Chem. 1941, 139, 175.
3. Berson, S. A., and R. S. Yalow. Immunoassay of plasma insulin in Immunoassay of Hormones. Ciba Foundation Colloquia on Endocrinology, G. E. W. Wolstenholme and M. P. Cameron, Eds. London, J. \& A. Churchill, 1962, vol. 14, p. 182.

4. Bürgi, H., W. A. Müller, R. E. Humbel, A. Labhart, and E. R. Froesch. Non-suppressible insulin-like activity of human serum. I. Physicochemical properties, extractions and partial purification. Biochim. biophys. Acta (Amst.) 1966, 121, 349.

5. Antoniades, H. N., J. A. Bougas, R. CameriniDavalos, and H. M. Pyle. Insulin regulatory mechanisms and diabetes mellitus. Diabetes 1964, $13,230$.

6. Mayerson, H. S. The physiologic importance of lymph in Handbook of Physiology, Circulation II, W. F. Hamilton and P. Dow, Eds. Washington, American Physiological Society, 1963, p. 1064.

7. Conard, V. Mesure de l'assimilation du glucose. Acta med. belg. (Bruxelles) 1956, 37.

8. Franckson, J. R. M. Mesure de l'activité de l'insuline chez l'homme. Acta med. belg. (Bruxelles) 1958, 23.

9. Froesch, E. R., J. B. Reardon, and A. E. Renold. The determination of inulin in blood and urine using glucose oxidase for the removal of interfering glucose. J. Lab. clin. Med. 1957, 50, 918.

10. Constable, B. J. Estimation of Evans blue dye in blood plasma and its application to blood volume determination. Clin. Sci. 1958, 17, 597.

11. Soeldner, J. S., and D. Slone. Critical variables in the radioimmunoassay of serum insulin using the double antibody technic. Diabetes 1965, 14, 771.

12. Renold, A. E., D. B. Martin, Y. M. Dagenais, J. Steinke, R. J. Nickerson, and M. C. Sheps. Measurement of small quantities of insulin-like activity using rat adipose tissue. I. A proposed procedure. J. clin. Invest. 1960, 39, 1487.

13. Yoffey, J. M., and F. C. Courtice. The formation of lymph in Lymphatics, Lymph and Lymphoid Tissue, 2nd ed. Cambridge, Harvard University Press, 1956, p. 53.

14. Grodsky, G. M., and L. L. Bennet. Time sequence in the release of insulin: the effect of glucose, glucagon and potassium. Diabetes 1966, 15, 521.

15. Daniel, P. M., M. M. Gale, and O. E. Pratt. The concentration of radioactive iodine in the thyroid lymph, thyroid venous blood and peripheral blood of primates. J. Physiol. (Lond.) 1963, 169, 330.

16. Amoroso, E. C. The biology of the placenta in Gestation, Transaction of the Fifth Conference, C. A. Villee, Ed. New York, Macy Foundation, 1958 , p. 15.

17. Skinner, S. L., J. W. McCubbin, and I. H. Page. Angiotensin in blood and lymph following reduction in renal arterial perfusion pressure in dogs. Circulat. Res. 1963, 13, 336.

18. Rusznyák, I., M. Földi, and G. Szabó. The special anatomy of lymphatic system in Lymphatics and Lymph Circulation. Oxford, Pergamon, 1960, p. 79. 
19. Rasio, E. A., J. S. Soeldner, and G. F. Cahill, Jr. Insulin and insulin-like activity in serum and extravascular fluid. Diabetologia 1965, 1, 125.

20. Frederickson, D. S., and R. S. Gordon, Jr. Transport of fatty acids. Physiol. Rev. 1958, 38, 585.

21. Samols, E., and V. Marks. Disappearance-rate of endogenous insulin in man. Lancet 1966, 2, 700.

22. Ørskov, H., and N. J. Christensen. Disappearancerate of exogenous human insulin. Lancet 1966, 2, 701.

23. Vinnick, L., and N. Freinkel. Basal insulin turnover. Clin. Res. 1966, 14, 290.

24. Cerasi, E., and R. Luft. Insulin response to glucose loading in acromegaly. Lancet 1964, 2, 769.

25. Rusznyák, I., M. Földi, and G. Szabó. Origin of lymph in Lymphatics and Lymph Circulation. Oxford, Pergamon, 1960, p. 175.
26. Mahon, W. A., J. Steinke, G. M. McKhann, and M. L. Mitchell. Measurement of $I^{181}$-insulin and of insulin-like activity in cerebrospinal fluid of man. Metabolism 1962, 11, 416.

27. Majno, G. Ultrastructure of the vascular membrane in Handbook of Physiology, Circulation III, W. F. Hamilton and P. Dow, Eds. Washington, American Physiological Society, 1965, p. 2293.

28. Samaan, N., R. Fraser, and W. J. Dempster. The "typical" and "atypical" forms of serum insulin. Diabetes 1963, 12, 339.

29. Antoniades, H. N., A. M. Huber, B. R. Boshell, C. A. Saravis, and S. N. Gershoff. Studies on the state of insulin in blood: properties of circulating "free" and "bound" insulin. Endocrinology 1965, 76, 709.

\section{NOTICE TO SUBSCRIBERS}

Post Offices will not forward the Journal when you move.

Please notify The Journal of Clinical Investigation, The Rockefeller University Press, Box 261, New York, N. Y. 10021, when your address changes. Include your zip code number. 